\title{
Panel Discussion: Environment and Multiple Use ${ }^{1}$
}

Panel Moderator: Dr. Robert G. Rosehart, President, Lakehead University. I think most of you were here for the earlier panel discussion and I must admit it's going to be a tough act to follow. According to my program, I was to make a statement and it will be short as I have a vested interest in lunch.

If you look at forestry and the forest industry, I think there's probably been too much focus on the trees. It's almost cute today that we have some trees out in front of us here. I know they're there as a symbolic gesture but I think there's more than symbolism in it. More and more, as several speakers have said in the last couple of days, the focus is going to have to be on people.

My own perspective on forestry and the forest industry from the standpoint of the discussion here on environment and multiple use, is that, to a large extent, it's been a bum wrap. If you look at the individual philosophies and ethics of people in the forest industry, I would stand them up to any citizen, any person on the street, with respect to environmental issues. A couple of times in the last day or so, there was a bit of tendency, I think, for the industry to blame the media and I would say your perception on the media depends usually on the press you get. I don't want to defend the media or Mr. Webster and his group, but they look for confidence in your position and I think the challenge in the future is going to be, in this industry and others in Canada, to manage change. No one sector does it - government, the industry or the broad forestry community - be it unions, academia or whatever. It's going to require pulling together and it's easy to sit around meetings like this and talk about it but it's another thing to get out and do it.

If you look at government they are having a hard time, collectively, paying for what they're doing now. I caution you not to expect them to be doing much more unless they can find some way of unloading some baggage. If you look at the business community, the corporate people I talk to are having a hard time making profit and they're trying to become more and more competitive to be able to allow Canada to stay in this business. The research establishment, too, be they in academia or in government, are under a lot of pressure and some of the ideas suggested to do some more research to focus on these long-term problems have been suggested for years but the money hasn't been there. The sobering message that I would put across is that all of this sounds good and some of it should be done, but I think there's going to have

These are the opening statements by members of the panel. Debate that followed is not included. to be a much more defined strategy and you're going to have to be realistic about what can be done.

Panelist: W.B. Gayle, Vice President, Canadian Forest Products Ltd. First may I, through you Mr. Moderator, do a reverse twist here and welcome Mary Collins, our MP from West Vancouver. She asked me the other night would she learn anything if she came here and I said of course she would and I'm sure, to this point at least, she hasn't been disappointed.

May people say that compromise will solve land-use problems and in the next three minutes I want to analyse that word compromise, give and take. Some people who think they are as wise as Solomon believe that land-use conflicts can best be resolved by compromise. They make motherhood statements that there should not be conflict or antagonism: instead find some middle ground. There are only two important statements here and this is one of them. Compromise embodies the concept of an exchange that is mutually beneficial and that can only happen when we are talking about integrated forest use. That is, integrating other forest uses with that of harvesting the forests. The second important statement is that, by definition, integrated forest use must include the use of the forest for growing and harvesting wood. So-called other uses then include forest lands that are flooded to provide hydro power, forest lands that are designated for wilderness purposes, forest lands in which a portion may never be harvested in order to provide a habitat that will maintain predetermined populations of fish and wildlife. You can't compromise when Fisheries and Oceans proceed on a nonet-loss policy or with forest lands in which a portion may never be harvested in order to preserve some unique values. If any of the preceeding is a stated objective in using forest lands, then we do not have integrated forest use.

Perhaps in parts of Canada there are some uncommitted forest lands, but in British Columbia all our forests are either parks, ecological reserves or forest management. So far if anybody wants to take any of that timber out for nonintegrated use, it's all take and no give because they haven't got anything to give, unless there is a trade-off for forest land in existing parks, wilderness areas or ecological reserves. To the forest manager or the logger, any watershed that's being alienated, any hectare, even that single tree is every bit as important to him as a cherry tree in your backyard is to you. Finally, one point in summary, if some wish to take forest land away from us, they had better have something to give in return in order to compromise, not just to compensate the forest manager for the reduced $A A C$ but also to compensate the 
logger and the mill worker dependent on the forest. UIC payments are no compensation. I believe in compromise but that means take and give.

Panelist: Verna Ledger, Director of Health and Safety, IWA Regional Council \#1. I would like to thank the planners of the conference for inviting me to participate on this panel and for the opportunity to comment on the presentations of the three speakers at this session on the environment. Since panel members have been given a limited time to review the presenters' remarks, I will deal only briefly with the issues discussed by two of the speakers and confine my remarks mainly to the presentation of Mr. Armson.

First I believe the topics covered by the speakers dealt quite specifically with environmental issues but from entirely opposite ends of the spectrum. The wide-ranging and diverse opinions, it would appear, represent somewhat a polarity of thought.

Two of the speakers dealt with the necessity for compromise. Mr. Cuthbert asked "what does the forest mean to Canada?" He answered his question by stating it means jobs and revenues, but goes beyond those basic issues and also means jobs and revenues for tourism, clean water to drink and a habitat for wildlife. He went on to say a forest must be valued for more than its sustainable yield and that "we cannot afford to forget that forests provide us with clean air and clear water, and are the basis of an immensely complex ecology." Mr. Thomas said, and I quote, "the battered concept of multiple-use forestry is still held up as an ideal, not because forest managers have done an acceptable job of practising multiple-use forestry but because the idea is a good one." $\mathrm{He}$ went on to say that the technical capability to actually practise multiple-use forestry exists: all that is lacking is the willingness and ability to commit the necessary resources and bear the necessary direct and opportunity costs. Both speakers suggested that the forest must be seen as a multi-purpose, renewable resource but if we are to move towards a multidisciplinary approach to managing it, the knowledge and capabilities of a number of professionals must be brought into the flow of advice to the decision makers.

As a union, in the forest industry, we would wholeheartedly agree with that statement. But I would remind the speakers that this process should include forest industry workers. Very often workers, as a group to be consulted, are ignored. When we protest that we have not been included, we are told we are part of the public which is being consulted: but let me say that very often the interests of forestry industry workers are not the same as the interests of the so-called public, because often the issues for workers become one of jobs vs. environment or workers health and safety vs. intelligent forest management as suggested by Mr. Armson. So it is vital that the forest industry workers also be included in the consultative process.

It goes almost without saying that the recommendations of at least two of the speakers for sound land use ethics to be established are supported by forest industry workers and their unions. Unfortunately, while we support the connection between good forest management and a healthy forest environment, currently neither is practised. The IWA supports multiple use of our forests and we believe it can be done if there is some give and take on all sides of the issue. Obviously, it is not impossible. Other countries such as Sweden have achieved an acceptable balance. Surely we can learn from those countries but it must be done soon before it is too late.

As I mentioned earlier, I would like to deal more specifically with the presentation of Mr. Armson who appears to be proposing the use of more and more chemicals as the only way to manage and sustain a viable industry. Since my professional background is occupational health and safety in particular I am Director of Health and Safety for the International Woodworkers of America - I am concerned about any proposal to increase the use of chemicals in the forests of Canada. Perhaps you are asking, as I did, why a safety and health professional was invited to be a panel member on the discussion of the environment and multipleuse forests, but l've reached the conclusion that it was not a bad idea after all since I believe that this is one perspective of forest management which has basically been ignored.

In Mr. Armson's presentation, once again, workers in the forest industry are ignored. While he does mention the possible concerns of the public, he does not mention the concerns of the workers. Although workers in the industry would be on the receiving end of the major contamination from these chemicals, they are not considered. Mr. Armson appears to minimize the problems of increased chemical use. He argues lack of evidence in the case of 2-4-D and 2-4-5-T and cites media hype and emotional response of the public as being responsible for most of the objections to the use of pesticides and herbicides in forests. Mr. Armson even quotes a few newspaper articles such as the August 13th New York Times and the Atlantic Journal, which also supported conjecture about the use of 2-4-5-T. In spite of massive evidence to the contrary, Mr. Armson even suggests we are unduly concerned about acid rain or sulphur dioxide in our environment. Perhaps Mr. Mulroney was wrong yesterday when he said $60 \%$ of our forests may be affected by acid rain. $\mathrm{Mr}$. Armson quotes Professor Rapson who states, and I quote, "all chemicals known to man, both natural and synthetic, are present in the environment". To which I would comment natural chemicals are present in an environment because they have been there, in one form or another, since the beginning of time and there is little we can do about them. However, synthetic chemicals are only present in the environment because man put them there in the first place. Again, Mr. Armson quotes Mr. Rapson who said, and I quote, "all are toxic in high enough doses, some are mutagenic, some are carcinogenic, some are teratogenic and some have other toxic effects". Then he said each has a concentration below which it does no harm, to which I would agree only if the concentration is zero exposure. However, a statement that each has a concentration below which it does no harm implies that research has been done and safe levels of exposure established for all, which is a completely erroneous conjecture. As any scientist, even the most conservative, would admit, so-called permissable concentration levels are based partially on research, partially on guess-work and partially on political decisions. In particular, politics plays a commanding influence on so-called acceptable levels of exposure.

As a rule, only when convincing evidence is available that chemicals have already produced serious toxic effects in exposed workers have governments and employers been willing to act to control or reduce exposure. In fact, in case after case, chemicals and levels of exposure once believed to be safe were later found to be causing devastating long-term health damage to workers like, for example, vinylchloride and benzine. With most chemicals there is a long latency period between exposure and the onset of the disease, particularly cancer. This makes it difficult to determine what the outcome may be, but wouldn't it be better to limit the workers' exposure in the first place than to wait for the body count? Mr. Armson quotes extensively the trials in Nova Scotia with regard to the proposed use of 2-4-5-T by a forest industry company. As he said, 49 scientists presented evidence at the trial but it was a judge, not a scientist, who made the final decision that, to his mind, not enough proof had been presented to suggest a 
serious heaith risk was posed by the use of the chemical spray. Obviously, in his mind, the evidence had to prove an immediate cause/effect. It's worth noting that the Swedish company which requested permission to spray was not allowed to use the same chemical mixture in Sweden because it had been banned due to scientific studies which related increased numbers of soft-tissue sarcoma to the chemical.

It ask you, how much proof is required? Wouldn't it be better to give the benefit of the doubt to the side of the workers or the public who is to be on the receiving end of the contaminant or are they to be used as guinea pigs? Obviously there are alternatives which require discussion to solve the problems of insects, disease and unwanted growth in intelligently managed forests. I believe that solving these problems is not impossible. However, it will take the full involvement of the forest industry unions in this process. I would like to repeat something Mr. Buchanan said yesterday. "Recognition of unions as full partners in developing the solutions is an absolute necessity if we are to be successful."

Panelist: Gregg Sheehy, Conservation Director, Canadian Nature Federation. Regarding Mr. Cuthbert's presentation, I completely agree with everything you said and I fully agree with your statement that environmentalists may have to concede that sometimes the best thing to do with a stand of trees is to log it, but there are also areas where the best thing to do is not to log. Your province of British Columbia has a parcel of land which is known as South Moresby, the southern $15 \%$ of the Queen Charlotte Islands. This area has timber values that are undeniable, but it also has natural values that are of international significance and it comprises only $2 / 10$ ths of one per cent of the productive forest land of British Columbia. For my organization, in the nearly 40 years of our existence, there has never been an area for which we have had greater concern for its preservation ro been more willing to devote our financial and other resources to see it protected.

Regarding Mr. Armson's statements, I have some concern specifically about your statements on acid rain. I don't disagree with what seems to be your main scientific point that the effects of acid rain on forests are not readily quantified, nor are necessarily a single, simple cause of their decline. But your words could be misinterpreted, I believe, or misused as an argument against emission controls for smelters, power plants or cars and trucks. The fact is that there is sound scientific evidence of the adverse effect of acidification on aquatic ecosystems and, to me, this evidence alone justifies emission controls. I teel that we need all the ammunition we can get in a fight against air pollution and, therefore, I think that the forestry community's role should be to say that acid rain or emissions, if you like, of oxides of sulphur and nitrogen, could be a problem for our forests and we need to do research to pin the problem down.

$\mathrm{Mr}$. Thomas is a recognized authority on wildlife and managed forests and I believe his presence here is recognition of the fact that Canada lags behind the U.S. in integrating forest management and wildlife management. The problems he identified are compounded in Canada by our really limited information base on our forest wildlife. We know something about our game species and their abundance and distribution and habitat needs, but we know very little about our non-game wildlife and we know virtually nothing about many of the lower forms of plant and animal life in an inventory sense.

My job is largely one of public relations. In the three years I've been with this organization, l've come to learn and believe I could say a lot of things to the forestry community about its dealings with the public but I believe that Rich Goulden is going to deal with that issue so l'll leave that to him.
Panelist: Rich Goulden, Director, Wildlife Branch, Manitoba Department of Natural Resources. Mr. Moderator, I will restrict my remarks to four items: purpose, perceptions, weeds and where to

Purpose. Coming at the tag-end of this Congress, believe it is fitting to remind ourselves of our original purpose for this gathering. Just to be sure that I'm in the right hall and not here under false pretences, the objective of the Congress, as 1 understand it, is to build a national commitment to the future of Canada's forests - underline national commitment. Now the fundamental precept underlying the Congress is that our forests are valuable to Canada both as an environmental and an industrial resource - environmental/industrial. The desired outcome of the Congress is, in quotes, "A strengthened public support for improved protection and management of our forests" - underline public support. But there's a certain inconsistency that kind of nags away at me after having looked at those. The vast majority of the Congress has been devoted to the industrial and trade aspects of forest management. Now, as important as these are, I'm certain, in fact I'm convinced, that environmental and multiple-use concerns are uppermost in the minds of many of the public at large, if not most of the public at large. Now, if this is so, how are we to achieve our desired outcome of a strengthened public support? Is it possible that we could be out of synchrony with the aspirations and the expectations of the average Canadian? Let's think on that.

Perceptions. Public perceptions are important; we ignore them at our peril. It may be true, as Mr. Armson claims, that the media can and has manipulated the public but I'm bothered by the fact that threaded throughout his analysis is the inference that public perception is inherently an inferior form of understanding compared with technocratic judgment. Let's remember that perception is defined by Webster - and I'm not takking about Jack now - as consciousness, awareness, the awareness of objects or other data through the medium of the senses, including the results of this, which is knowledge. Peters and Austin, the authors of the acclaimed text on "Leadership and Successful US Businesses", say there's only perceived reality. The real is what we perceive and it's interesting to note that the first commandment of the formal written customer-philosophy of a successful US forest products retailer says 'Feelings are facts'. I point out that in respect to most issues of global significance and historical import, perception is often all that's available at the time watershed-type decisions must be made. We, as scientists, are often quick to dismiss the views held by society on the grounds that they are mere perceptions. I would argue that public perception is as relevant and as vital to decisionmaking in a democracy as science is in a technocracy and once we decide which of these two forms of government we enjoy, the relative importance of public perception should no longer be an issue for debate. Remember, we in this Congress hall are preaching to the converted. A "national commitment" cannot take root in a seedbed of thinly disguised contempt for public perceptions and/or public involvement. Not much has been said here about land claims, not much has been said about public communication, we haven't dealt with the realities of the media environmental cartel.

Weeds. As a wildlife manager, I want to talk a little about weeds. You see, I wouldn't exactly be doing my duty if I did not raise a cautionary note over Mr. Armson's reference to the broadscale aerial application of herbicides to kill those socalled weeds. Now remember, in this case, one man's weed is another man's wildlife. If it's true that we want to manage forests for a multitude of benefits, we must be careful not to assume that all of the products and the values flowing thereform are subservient to wood and fibre and, therefore, analagous to weeds. Mr. Armson states that "what is even 
more inadequate, if not virtually nonexistent, is the effort to develop new materials, particularly biological alternatives for pest control and innovative approaches to vegetation management." Now, given this as the state of the art, why on earth should any member of the public or environmental group or wildlife professional be particularly reassured about the broadscale application of herbicides?

So, where to? If we want to build a national commitment, we must mobilize a truly national effort. This can be done only through a public awakening and a unified desire to set wrong things right. To mobilize the national will, I submit we must find and build upon the issues that unite us and with which we can all agree. Equally, we must be willing to exhibit flexibility on those issues that may be important but which are not absolutely essential to the attainment of our joint long-term goals. Now, as a wildlife manager, I've been down that road a few times and I've been bloodied a bit. In these matters the inevitable danger is wasting ourselves on the peripheral issues while letting the prize slip through our grasp.

So how do we mobilize national will? I think there are seven things that we can do - short and sweet. One, we should tell people forests are important to the economic, social and cultural fabric of Canada and the well-being of its citizens. Two, our messages must be positive. The forest industry must be positive about its contribution to history, culture and economy of this country. It must be assertive, confident, dignified and factual in its communications. Three, respond to public concerns. The forest industry must understand and respond to the legitimate concerns of the general and the specific public. Its messages must reflect the value systems of the public, the media and the political decision makers. To disregard public perception is to court disaster. Society will no longer tolerate single-purpose forest management; they will effectively shut down or frustrate the operations of those who willfully ignore public sentiment. Four, realize that there are wider issues. The forest industry must be aware of the evolving public attitudes towards forestry, wildlife and environmental relationships. The industry must demonstrate that even those people who do not live close to nature and who do not depend upon the forest resources for their livelihood have a legitimate stake in the use of the forests.
Don't be hesitant to engage in open two-way communication. In this connection, we may have to face the fact that there needs to be a renaissance in the thinking of many forestry professionals in respect to their dealings with the public and their sister professionals. Communication and training programs must be conceived accordingly. Let us not overlook the pregnant possibilities inherent in interdisciplinary executive interchanges. Five, squander not the birthright. In our desire to compete with other nations in supplying the world's demand for wood we must resist the temptation to exploit without replenishing, to downplay the importance of surrogate values or to underestimate the importance of diversity, stability and beauty in our forest landscapes. Six, simplify messages. The forest industry must not only present facts but must go beyond this to present simple and emotional communication themes which must be constantly reinforced. Without demeaning ourselves, we must simplify the messages and add just a touch of emotion. If we expect to win our case in the court of public opinion on the basis of scientific fact and economic data, don't be too sure. Emotional arguments will move people faster than scientific facts ever can. Lastly, support your supporters. Far too much time and energy and resources have been spent by the forest industry, reacting in a defensive manner to the accusations and the taunts of a few preservationists, both individuals and organizations. It's in your best interest to take an assertive rather than an aggressive or a defensive posture. Reach out for the great majority of the public which supports the principles of multipleuse forest management. Historically, renewable resource extraction industries have been notoriously independent, selfreliant and self-serving. The time has come, I believe, when that degree of individualism needs to be rethought. Networks with agriculture, wildlife harvesters and a host of other forest users are possible and they're profitable.

In conclusion, let us remember our purpose. Let's not give it lip service. If it's a national commitment to the future of Canada's forests we are seeking at this Congress, we'd better recognize that public values are there and be willing to adjust our objectives to accommodate them. Simply put, if we want national commitment, we must acknowledge public priorities. These include wildlife and there aren't any shortcuts. 